\title{
大規模住宅市街地の開発のための写真測量の \\ 系統的利用に関する考察 (承前) \\ On the systematic application of photogrammetric engineering for the development of lage scale residential area
}

\author{
丸安隆和 ${ }^{* *} \cdot$ 杉本幸治 $* * \cdot$ 田中総太郎 ${ }^{* * *}$
}

\section{2-6 写真測量を利用した土地利用計画}

土地利用計画はあらゆる面からその地域の最適性を 追求し, 将来の機能性, 安全性, 快適性を満たす方向 をとらなくてはならない。そのような土地利用計画を 作成できるために，図-30 に示すようなシステム化さ れた土地利用計画の協議のあり方を考える。ここにあ げてある方法は広い意味つマンマシンシステムといら ことができよう。

土地利用計画をする場合, その判断視点は個に分け ることができる。この 3 個の視点は同じ価值のレベル にあり, 広域判断, コミュニティとしての判断, 自然 地形判断である。

広域判断とは, 都市間, あるいは地域間の将来の発 展の関連性を推定し, 道路, 鉄道, 水道等の把握を行 ない, 対象地域周辺の状勢と環境を知ることである。 ここでは, 対象地域の全体の中に和ける位置ずけを知 り，どう対処するかを判断するのであり，そのための 資料として，小縮尺の諸種の都市概況図，あるいは地 勢図が利用できるであろらし, 対象地域を含々広く撮 影された写真地図も有効となるであるら。

コミュニティーからの判断とは, 主として社会科学 的な見地から見た人間集団のあり方である。これは他 の二個の判断視点と, 複雑にからみあって意味づけが なされる。しかしながら，この視点からの土地利用の コントロールは, 成果に重大な影響を与えると考兄ら れる。

自然地形による判断とは，土地利用が自然地形を生 かすためにはどうあるべきかというものであり，写真 測量により効果的に検討できる。居住地計画の場合, 住環境に密着した地形の影響とは, 日照の確保から要 求される斜面の方向, 機能性から要求される斜面の勾 配の強さ，人間は高い所を好も性質から要求される標 高, あるいは水道計画と直結する水系把握等がある。

この個 3 の視点より判断するために, 写真測量によ り提供することのできる資料として，写真地図，点ま たは線画により表現される各種の数值地図, あるいは 計画, 設計者の意図によって地形の特性を作成するい

「写真測量」Vol. 10, No. 4, 1971
ろいろな合成図面が存在するのである。

ここでは，例題として扱っている地域について，居 住地計画のための土地利用をこの 3 個の視点より考え てみる。

視点 I：広域判断この地域は現在は, 都市の周辺に 位置しておう, 緑地が多い。しかし, 都市が人口増の ため膨れあがると, この地域も,すっぽりと都市内部 に含まれ，住宅地となるであろう。この地域を規定す るものは交通網である。人口の過密による混乱を避け, 生活の快適性を向上させるために, 都心への連絡交通 路の充実をはかることと, 緑地, 空地を確保し, スペ 一スに余裕を持たせる方向をとることが考えられよ ら。

視点 II : コミュニティーとしての判断この地域の南 および西には川が流れており, これはこの地域に枠を はめる形となっている。また都市計画として, この地 域に環状線が通ることが予定されている。幅員 $25 \mathrm{~m}$ 級 の道路については, この地域の西側に, 現在竣工して いる道路を含め, 南特よび東側を通る予定になってい る。したがって，この地域を外部と連絡するものは, この四本の幹線道路となる。将来このような道路の下 に高速鉄道を通し, 輸送体系を改良してゆくことも充 分考えられる。この地域の骨格は以上のようなもので あり, 住宅地としては, 環状線によって二分された東 西の住区を基本に考慮できる。西の住区は, 池の付近 を中心地と考光, 公共施設, 小学校等を配置すれば, 地形は平坦であるため, 大きな施設用地として適し, どこからも等距離にあるためすべての市民から親しま れるであろう。

一方, 東の住区は, 現在区画整理が終了している付 近を中心施設用地にあて, このまわりの急傾斜地を, 公園緑地として保存することにより，緑に囲まれた街 を意識するコミュニティーが期待できよう。

視点 $\mathbb{I}:$ 自然地形判断一一自然地形はコミュニティ 一としての判断においてすでに考慮されている。ここ ではその基礎の上に立ち，地域の内部に打ける土地利 用計画のために自然地形との適合性を判断するのであ る。計画者は，地形の特性を把握するために，知りた 
いと思う地形特性を計算機に指定することにより，そ の特性を有する地点の分布を知ることができる。土地 利用を考慮する場合，なるべく現在の地形を生かそう とするのが基本となるので，現在の地形の特性を有効 に把握することが大切となる。

例題の地域では，斜面勾配が $1 / 4$ 以上の地点を抽出し てみると，傾斜地が多すぎて，このままでは，居住地 を計画しても機能性に欠けると思われる。このような 急斜面は，粗造成に扣いて，大きく切盛土するか，緑 地として保護することになる。できるならば，粗造成 を行なうと土量は膨大になるし，水系をも変更するよ らなことになるので，保護しておくほうがよいであろ う。集水面積区分図は，谷筋を表わしているものなの で，水系としてそのまま維持し，下水道の問題を解決 し，住宅地の高燥性を確保するために，このような水 系を道路に供するとよいであろう。 また道路の下は下水流下路となる。 中心施設用地は，すでに東西の住区 の各中心がよいことになっている が，地形的にも適している。住宅そ のものの適地の選定としては斜面勾 配の強さ打よび方向を合成した図面 を作成し，おもに南向斜面で勾配が 1/8以下の地点を独立住居地に，南向 き以外の斜面で, 勾配が $1 / 10$ 以下の 地点を集合住宅地に選ぶこともでき る。

このような選定は，地形特性を検 出し, 計画者が写真地図を見ながら， 全体的な把握を行ない，縦横断図に より局部的な地形の変化を知って, 施設の連絡，交通体系を考兄つつ試 行錯誤の繰り返しにより遂行される ものである。

\section{III 住宅地域計画の土地造 成におけるマン・マシン システムについて}

写真測量により数値地形モデルを 構成するもら一つの利点は, 多大の 労力を要する土工量の計算を, 計算 機に半自動的に肩代りさせることに ある。住宅地域計画に和いては，地 域が面的な広がりをもっているた め, 土地造成と一言でいらものの， その中には線的な道路とか, 面的広 がりを有する公共施設の平坦な敷地

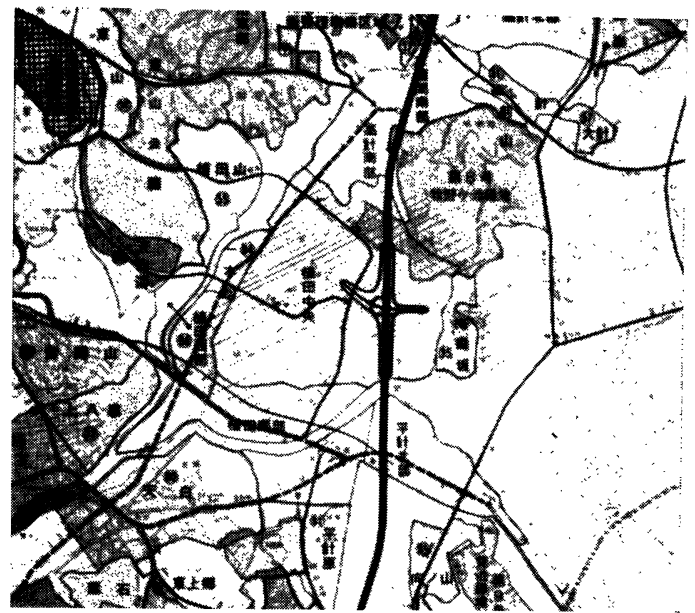

図-25 都市計画図の例

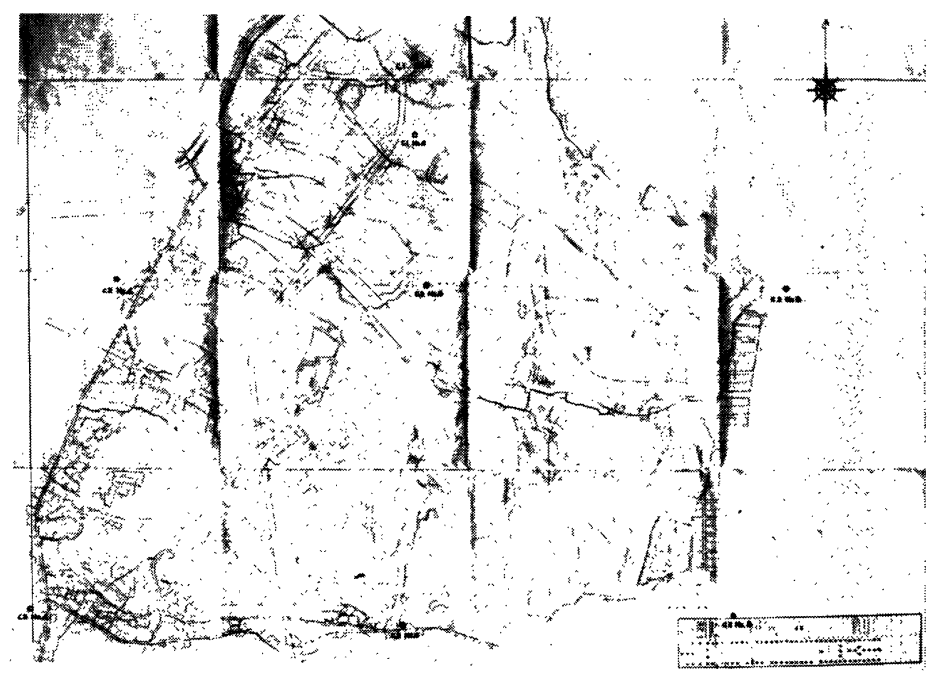

図-26 街路配置予定図の例

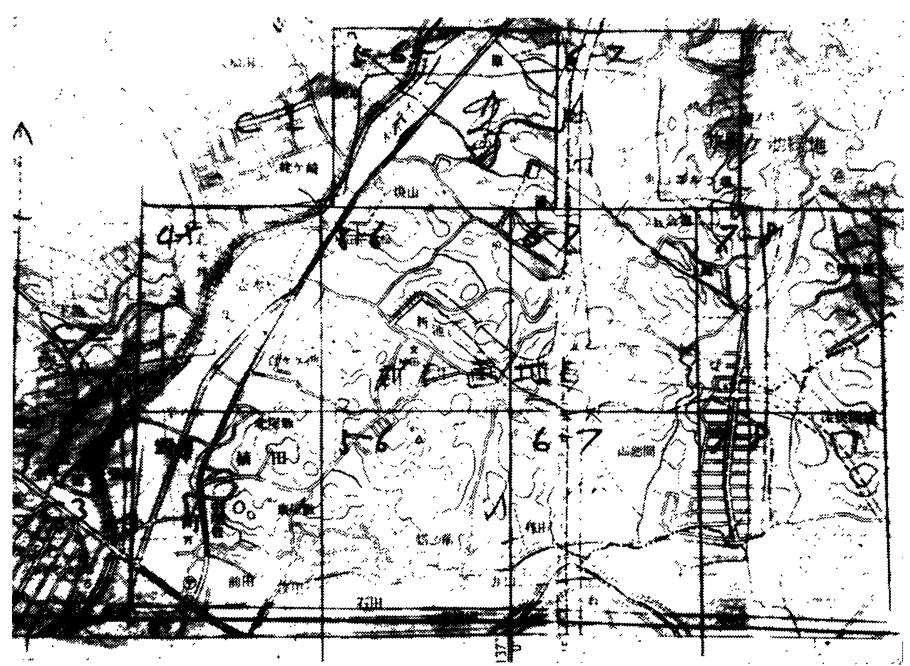

図-27 現況検討用図面の例 


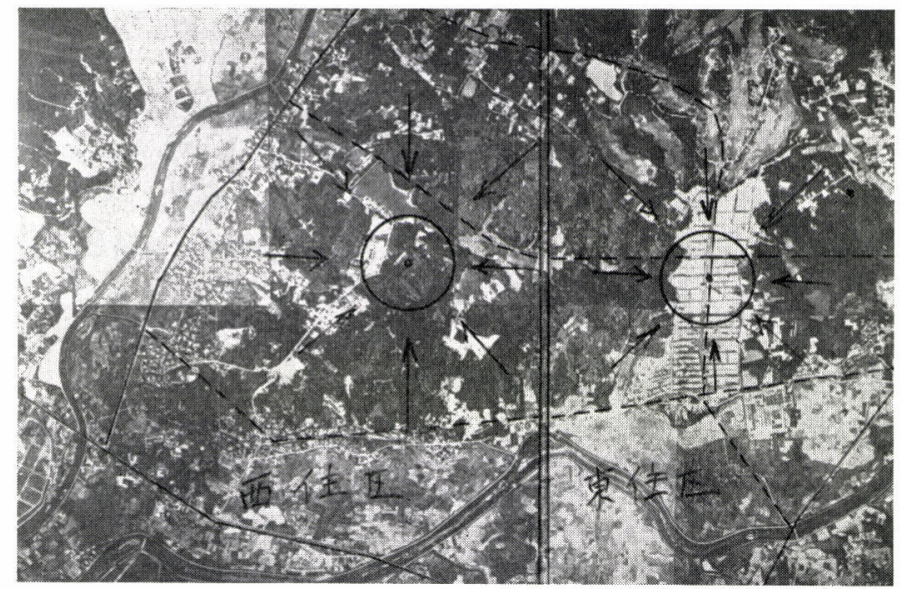

図-28 写真地図によるコミュニティ構想の例

とか，宅地の敷地を造成するための粗造成基面等の決 定が含まれる。

また施工時に抢いては，土量の配分の問題も派生し てくる。したがって，住宅地域の土地造成を考学る場 合は，はじぬに各論的になるか゚，数值地形モデルを使 い，道路，平坦な大きな敷地，宅地の粗造成のそれぞ れの施工基面を決定する方法について考察し，これら の打の打のを⿱とめることを，より高度のレベルでの 人間の判断体系としてとらえることになるう。

\section{3-1 道路の概略設計}

道路は数値地形モデルの中に䗆いて線的に伸びてい

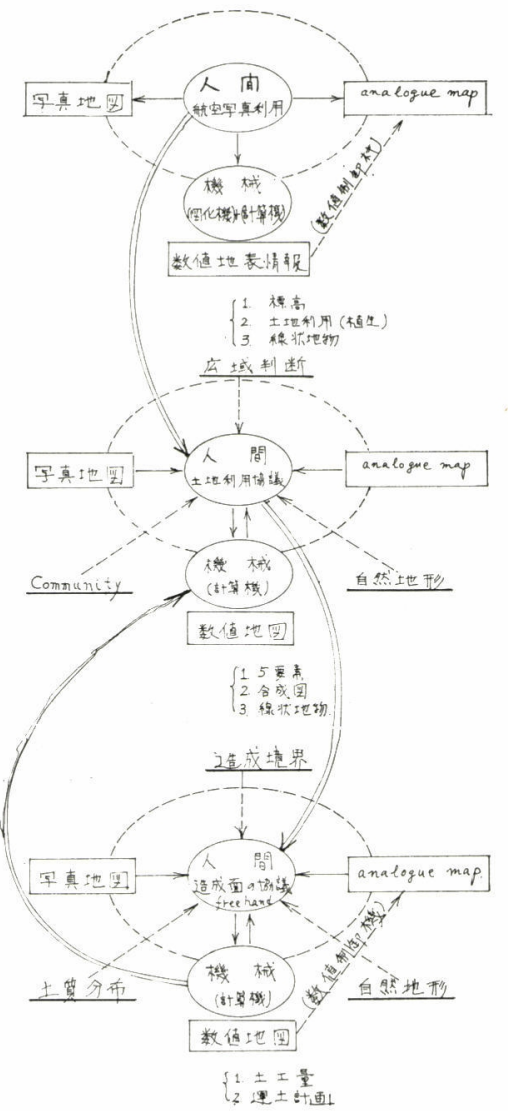

図-30 写真測量を応用した住宅市街地 計画のモデル

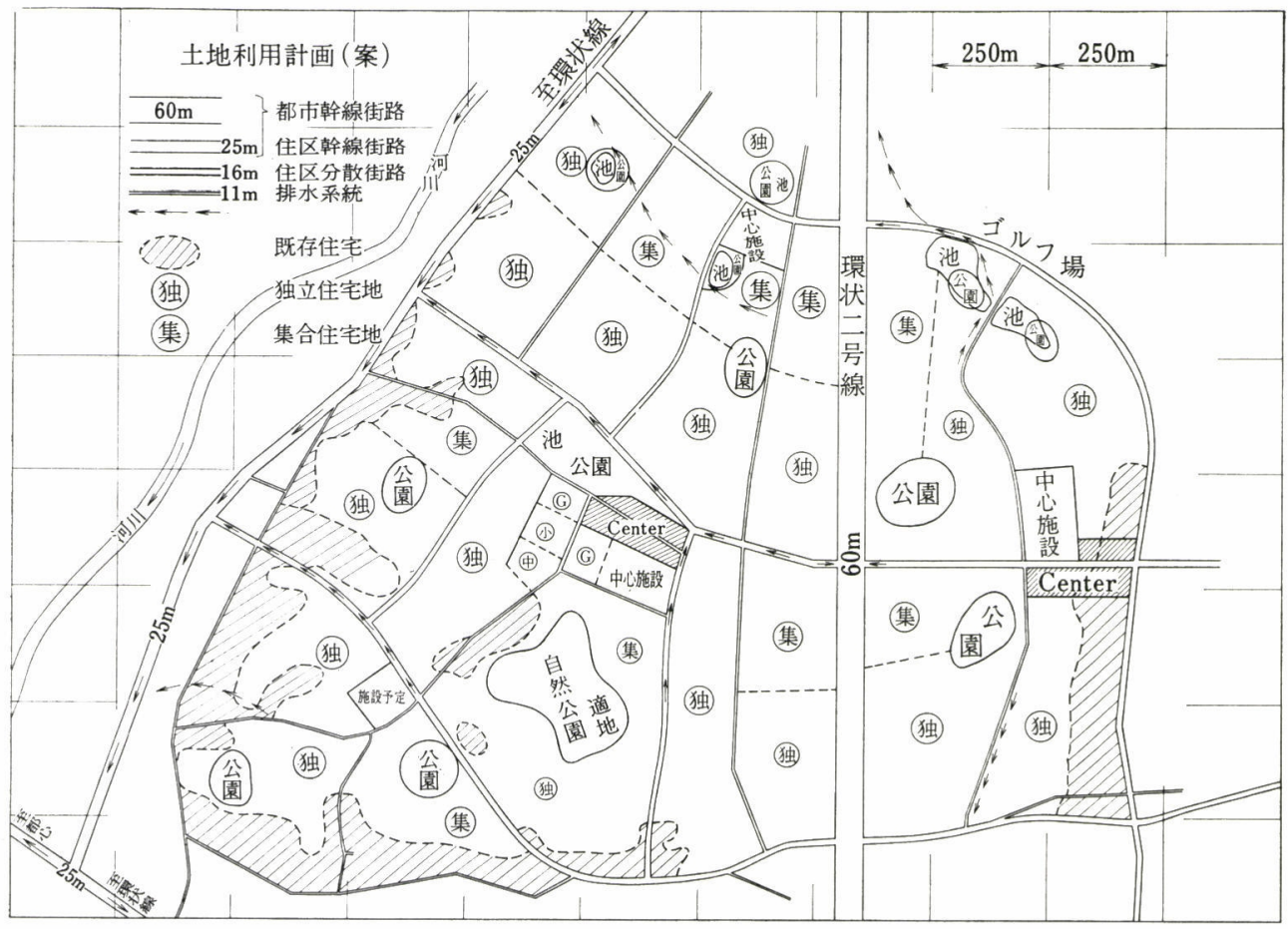

図-29 土地利用構想の一例 
るので，道のりにそって道路の $(X, Y, Z)$ 座標値の配 列を計算機に入力することにより，土工量が計算され る。土工量計算そのものは，計画する道路の高さと， 原地形の高さの差をとればよいので, 問題は少ないが, 道路の平面位置の選定と縱断位置を選定することが問 題となる。従来，工費を最小にすることを目的とする 自動路線選定の研究報告がされているが，ここでは， 住宅地域内の縦横にはしる道路が主になるので，試行 錯誤によるフリーハンドの視覚設計の方向が妥当では ないかと思われる。
たとえば，まず道路の平面位置の選定を行ない，つ ぎにこの平面位置の座標值の配列を入力してやり，各 点の標高を内挿計算により知り，現地形の縦断図をグ ラフィックアウトする。この四形について，縦断線型 をフリーハンドにより設計する。この結果を再び計算 機に入力し，土工量を計算したり，道路と道路との接 合点を考慮して，繰り返し修正してゆくものである。

\section{3-2 公共施設のための広い平坦地の設計}

学校とか運動場のような広い平坦地が必要なものを
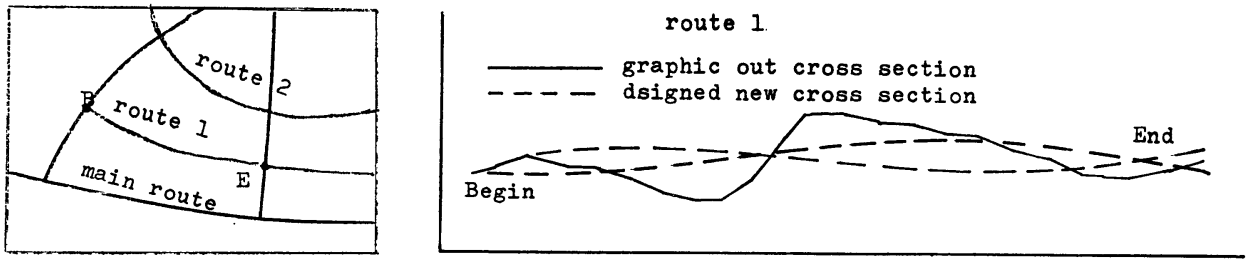

図-31 道路の概略設計の方法

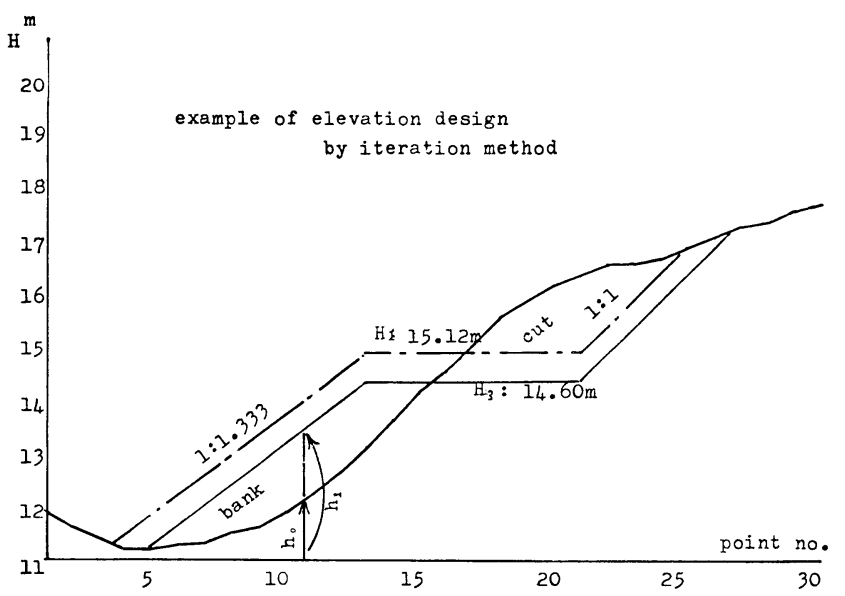

図-32 Example of elevation design by iteration method

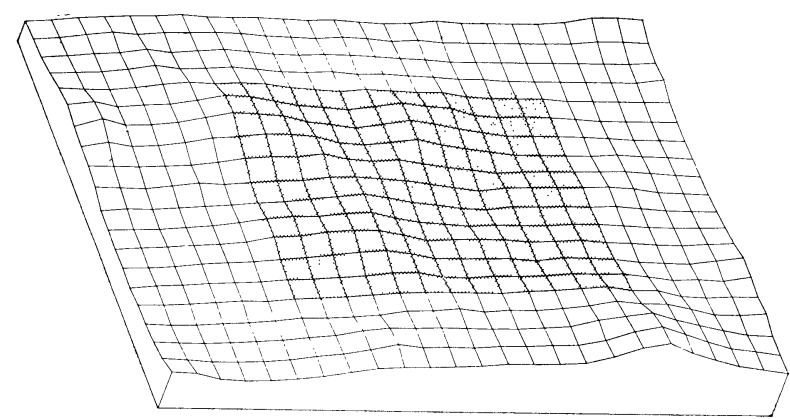

図-33運動場の整地のデザイン例（原地形）
計画するには, 执よそ決定された地点で, どこに選ぶべきか，どのような施工基面 にするかを検討する必要がある。施工基 面を決定する方法については，2 個の考 え方に分けることができる。一つは施工 基面を指定して，その水準面に敷地を造 成するものであり，もら一つは，施工基 面を土工量がバランスする水準面に算定 するものである。

わかりやすくするために，二次元のモ デルにより土工量の計算と, 土工量のバ ランスする水準面の算定につい述べる。 図-32 に示すように傾斜面に幅 $4 \mathrm{~m}$ の平 坦地を作る場合を考える。原地形が等間 隔の点列に対応する標高により与えられ ている。このとき, 平坦地の平面位置と 大きさ，拈よび造成斜面の勾配は与兄ら れているものとする。点列の $i$ 番目に対 応する原地形の高さを $h_{0 i}$ 造成地形の高 さを $h_{1 i}$ とすると，切土量と盛土量は

$$
\begin{aligned}
& \text { 切土量 }=\Sigma^{i}\left(h_{01}-h_{1 i}\right) \\
& \text { ただし }\left(h_{0 i}-h_{1 i}\right)>0 \text { の点に摘要 } \\
& \text { 盛土量 }=\Sigma^{i}\left(h_{1 i}-h_{0 i}\right) \\
& \text { ただし }\left(h_{1 i}-h_{0 i}\right)>0 \text { の点に摘要 }
\end{aligned}
$$

として計算できる。切土量と盛土量がバ ランスする水準面は, 切土量と盛土量の 差を加算した点の数で除算すれば，これ が修正する標高差になるので，これより 
水準面がわかる。この図に示した例では，施工基面 $H_{1}=15.12 \mathrm{~m}$ を土工量がバランスする初期値として与 え，標高差一0.52mを補正して，土工量のバランスす る $H_{3}=14.60 \mathrm{~m}$ を計算したものである。

一般には，整地はその形状と平面位置とが与えられ るので，土工量の計算も，平面的に配列してある点の 集まりに関して行なら。その例として，運動場の整地 のデザインを行なった例をあげておく。

\section{3-3 住宅地の粗造成整地の考え方}

住宅地域を丘陵地に造成する場合, 全面整地を行な う場合がある。このばあい，通常，粗造成面を試行錯 誤により決めているが, 最近は計算機により, 粗造成 面の試案を設計する方法がとられるようになってい る。粗造成面を規定する条件は，まず斜面勾配の制限 である。つぎに水系は原地形のるのを維持するのが望 ましいであろう。さらに, 宅地造成地域外との境界に 打いて，崖になるような造成は避けるべきである。

ここでは粗造成の試案を計算する一つの方法につい てのべる。この方法は, 地理学に执いて知られている 地表面の輪廻，すなわち，急峻な山脈が，雨水の流下 により次第にまるみを乱びたゆるやかな丘陵に変化す るといら過程より類推している。粗造成の設計では, ただ地形が変化すればよいのではなく，制約条件とし て，変形量をなるべく少なくし，現地形を生かし，経 済的にすること打よび，造成斜面の勾配を適当なもの に拉さ兄，日照，機能性等を確保することを考兄て計 算されなければならない。そのための計算法に次のよ らなものをあげることができる。

粗造成面の計算方法……全面整地を行なら領域が数 值地形モデルとして，配列 $H_{m, n}$ により与兄られてい るとする。 $(i, j)$ 点に着目し, この点の地盤高を $H_{i, j}$ とする。隣りにある 4 点を比較して, 最も低い地盤高
のものを選ぶ。いま，かりに $H_{i, j-1}$ が最も低いとし よう。東西南北の各向きの斜面により制限勾配が与兄 られるから,この場合も, 相応した地盤高の標高差が ある。これを越える場合は， $H_{i, j}$ より hだけ切土をし て， $H_{i, j-1}$ にんだけ盛土をすればよい。hは $H_{i, j}-H_{i, j-1}-2 h=$ 許容される地盤高の差 となるように決める。

このような切土，盛土を全点にわたって行ない， $H_{i, j}$ と同じ対応をしている切盛土計算用配列 $B_{i, j}$ に切 土ならばーh，盛土ならばｈだけ加算してゆく。全 部の点について計算された土工量 $B_{i, j}$ を現地盤高 $H_{i j}$, に加算すると造成地盤高が出てくる。但し，1回の操 作では，勾配の制限を満たさないので，計算された造 成地盤高を, 再び現地盤高と考兄, 第 2 回目の造成地 盤高を計算する。このような繰り返し計算を 100 回す れば，ほとんど制限を満たす粗造成地艋高を得ること ができる。図には, ディジタルマップとして, 原地形, 造成地形，切土盛土量の等高線図を示してある。なお， この例では，北東東向きの斜面は制限勾配 $1 / 10$, 南向 きの斜面は $1 / 8$ とててえてある。

\section{3-4 線型計画法による土量配分}

土地造成の場合, 土量配分も問題になるが，これは 線型計画法に怙ける輸送問題と考光ると, 適切なる解 が得られる。

土量配分を行ならべき地域を, たとえば $60 \mathrm{~m} \times 60 \mathrm{~m}$ の区画にわけ，この区画に扔ける切土量または盛土量 を数值地形モデルより計算する。これらを $c_{i}(i=1 〜$ $k), b_{i}(i=1 \sim l)$ とする。また，採土可能な区画，捨 土可能な区画の土量を $p_{i}(i=1 \sim m), \quad d_{i}(i=1 \sim n)$ と 指定する。ここで土量が配分されるための条件は，各 \& $c_{i}, b_{i}, d_{i}, p_{i}$ について

$$
\begin{aligned}
& c_{i}=\sum_{j} b_{i j}+\sum_{j} d_{i j} \\
& b_{i}=\sum_{j} c_{i j}+\sum_{j} p_{i j} \\
& d_{i} \geqq \sum_{j} c_{i j} \\
& p_{i} \geqq \sum_{j} b_{i j}
\end{aligned}
$$

が成りたっていることである。

線型計画法を摘要する目的は，土量配 分を最小の費用で行ならこととし，距離 により $1 \mathrm{~m}^{3} を$ 運ぶ価格を仮定する。たと えば $1 \mathrm{~m}^{3}$ の土を $x^{m}$ 運ら゙ためには

$$
y=226 \log _{10} x-186 \text { 円 }
$$

$$
(30 \mathrm{~m}<x<5000 \mathrm{~m})
$$

かかるとする。 $i$ 区画から $j$ 区画への距 離を計算すれば, その場合の単価 $y$ 円が わかるから，これを目的函数の各係数と 
し、 $u_{i j}$ と括けば

土量配分費 $=\sum u_{i j} b_{i j}+\sum u_{i j} c_{i j}+\sum u_{i j} d_{i j}$

$$
+\sum u_{i j} p_{i j}
$$

となる。

輸送問題を線型計画法で解く場合, タブローの中に 現われる数がー $1,0,+1$ に限られるので， 2 ビッ ト演算を行ならことができ,一般の線型計画の問題よ

表-2 土量配分の可能性を表示した表

\begin{tabular}{|c|c|c|c|c|c|c|c|c|c|}
\hline 1 & $b_{1} b_{2}$ & b3 & $b_{i}$ & & & $b_{k}$ & $d_{1} d_{2}$ & $d_{j}$ & $\mathrm{~d}_{\ell}$ \\
\hline$c_{1}$ & 1 & 1 & & 1 & & & & 1 & \\
\hline c2 & 1 & & 1 & & & & 1 & & \\
\hline c3 & & & 1 & 1 & & 1 & & & 1 \\
\hline$c_{m}$ & & & 1 & & 1 & & 1 & & \\
\hline$p_{1}$ & 1 & & 1 & & & & & & \\
\hline p2 & & 1 & & & & & & & \\
\hline$p_{n}$ & & & 1 & & & 1 & & & \\
\hline
\end{tabular}
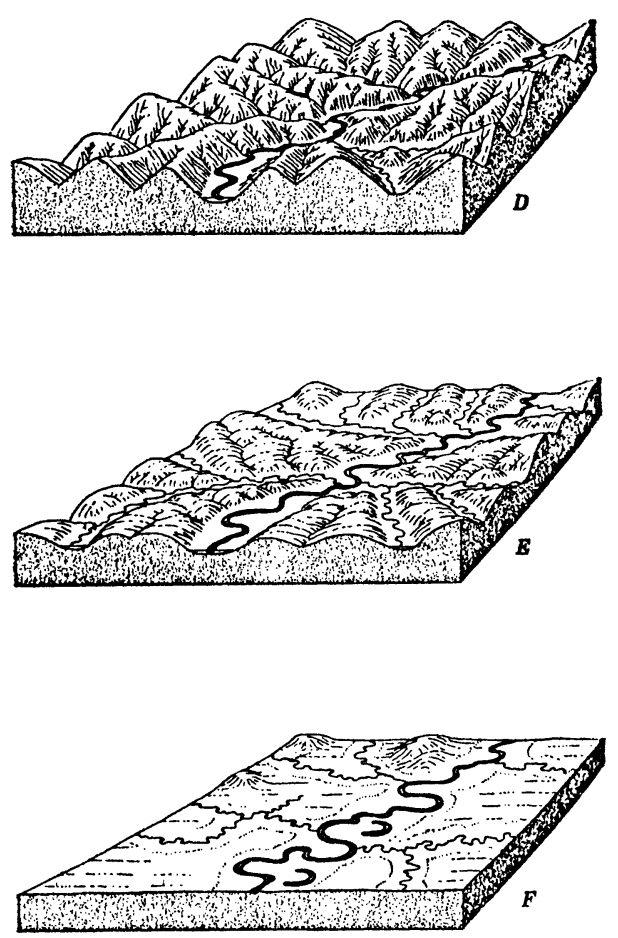

図-34 粗造成の計算方法の類型
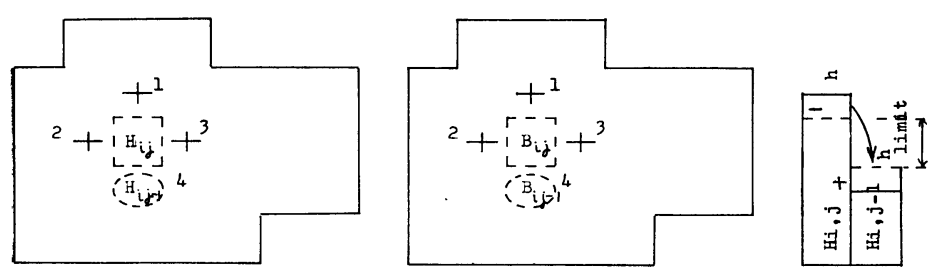

図-35 粗造成面の計算方法
りも変数の多いものを扱うことができる。しかし，明 らかにありえない土量配分の方向を持つものは除去す るのがよい。そのためには，土量配分が可能と思われ る組合せを 1 で表示した表を作成し，それ以外の組み 合せは変数に考慮しないで計算する。この方法で土量 配分を行なった例をあげて扔く。比較するために, 専 門家が勘によって土量配分を行なったものを並べてお く。これによると, 線型計画法による土量配分計画の ほうが，経費にして $2 \%$ 強軽減されている。したがっ て, まず線型計画法により大概の土量配分を計算し, これをもとに，考慮すべき諸条件を加味した計画をた てるのがよいのではなかららか。

\section{3-5 土地造成におけるマンマシンシステム}

土地造成に和けるマンマシンシステムは, 現在コン ピューターグラフィックスの例としてあげられている 曲面のフェアリングとか, 電車の運転のシミュレータ 一のような完全なコンピューターと人間との対話とし ては成り立たないであろう。なぜならば, コンピュー ターグラフィックスの技術レベルが，現段階では高度 な図面に摘要するまでに至っていないことと，人間の 䚾うも，計画，設計の修正を即興的に考劣ることは問 題が多いと思われるからである。ここでいらマンマシ ンシステムの方向は, 人間が設計対象に関して, よく 熟考する。そして, そこに必要と思われる図面を, 視 覚化し, ハードコピーとして, 人間に提供することを コンピューターに指令し，それによってまた人間が考 えるといらことを意味するのである。

こうすることによって得られる利益としては，いま まで手作業をしなければならなかった部分を, 機械作 業に扣きかえ，いわば労の多い仕事を機械が処理して くれ，人間はもっと大切なことを深く考えることがで きることである。しかも手作業が機械に拈きか兄られ たことは, 計画設計の変更といらフィードバックシス テムを著しく容易にすることを意味する。

土地造成に执いては，考虑すべきものは，概略的な ものから, 細部に至るまで多様であり, 混久入ってい る。ここでは土地造成の計画設計の過程のアウトラィ ンを正しい方向で誘導してゆくといら希望をもってマ ンマシンシステムへのアプローチを考察しているので ある。

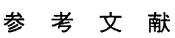

1）志摩茂嘉：宅地造成計画に関 する研究

2）丸安研究室 : 地形情報の抽出 とその自動処理

3）丸安隆和住宅地域計画のため のビジュアル・デザイン 「講談社」グラフイクデザイン号 


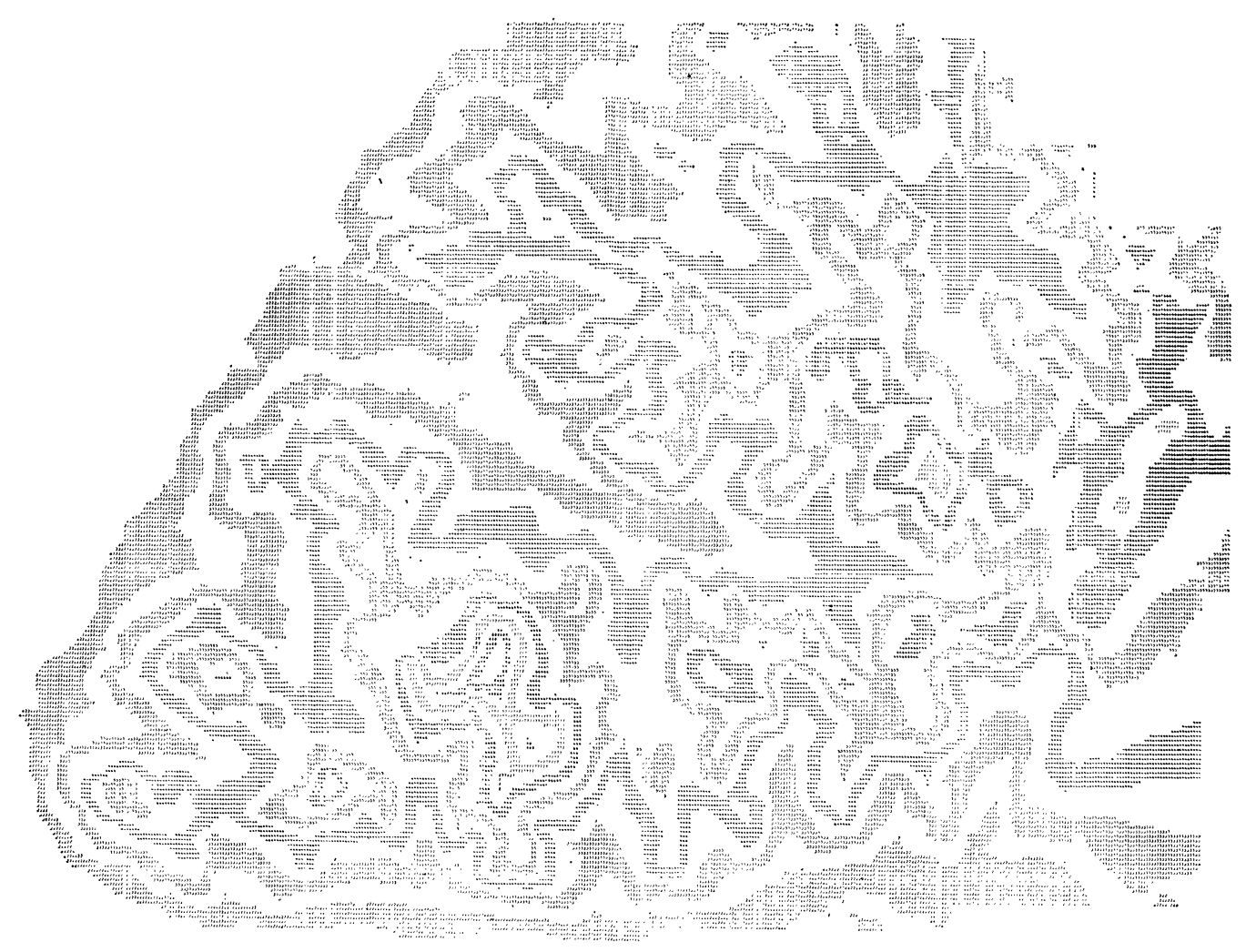

\section{図-36 粗造成面の設計例 a. 原地形}

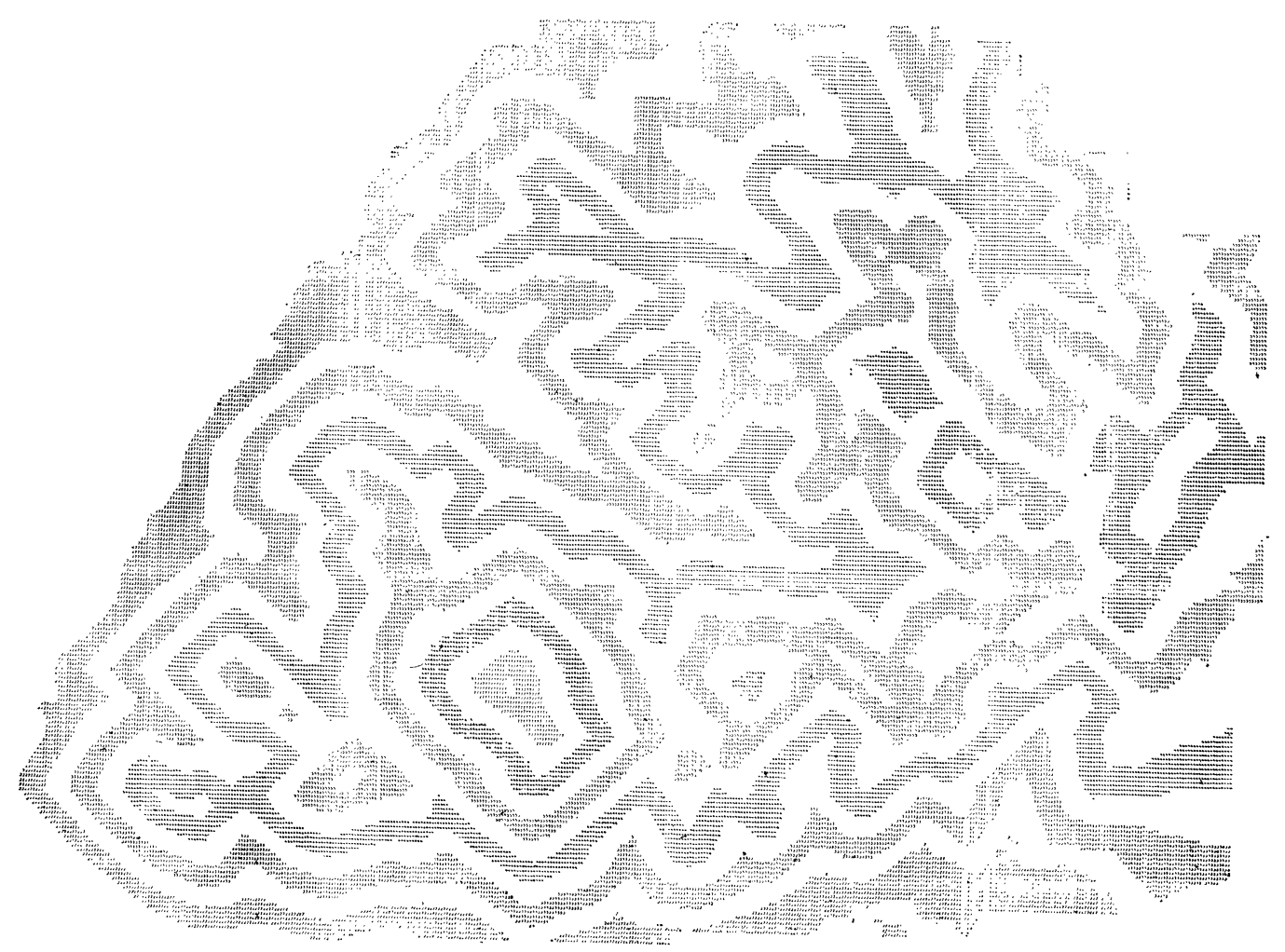




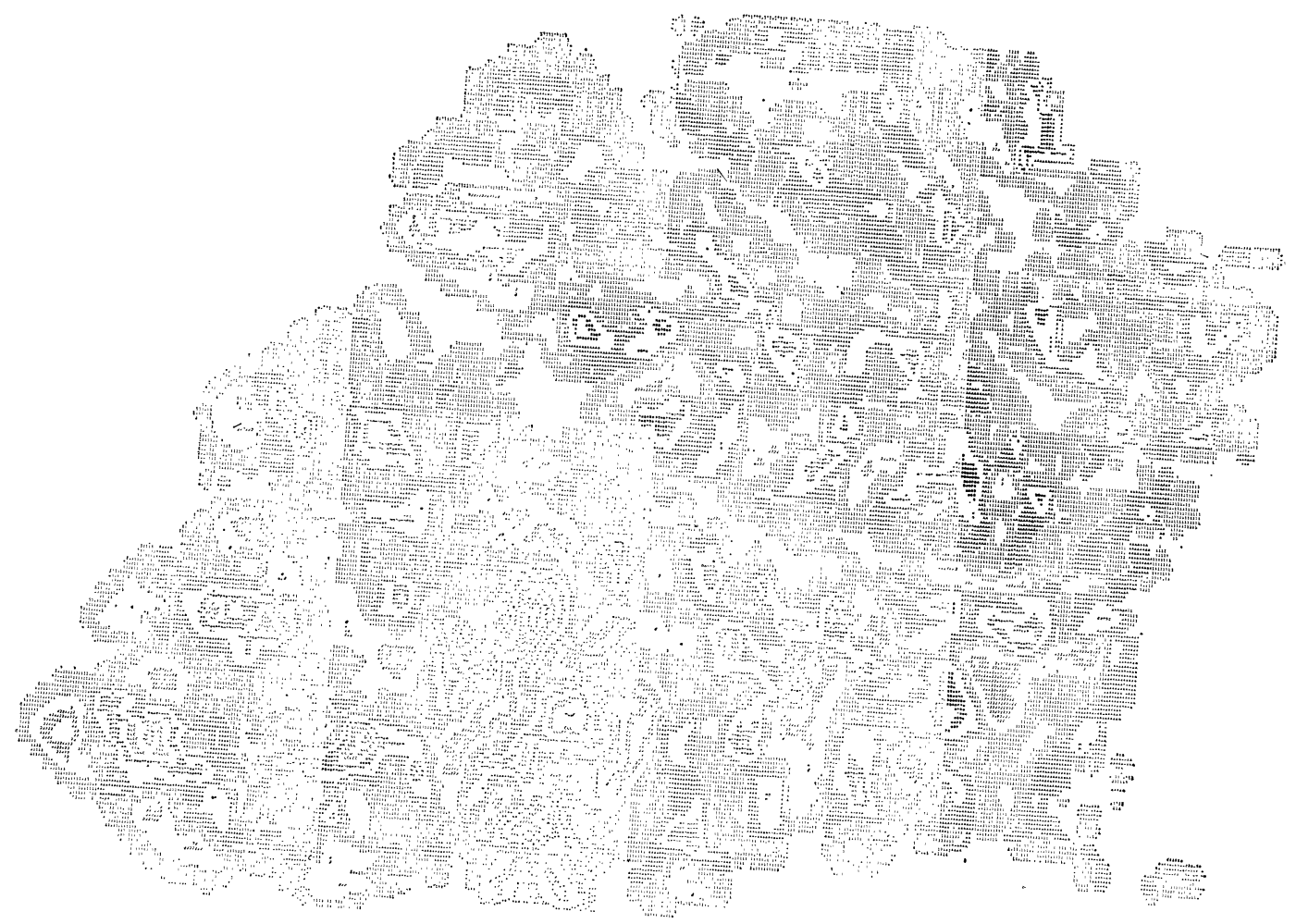

c. 切盛土量の図面

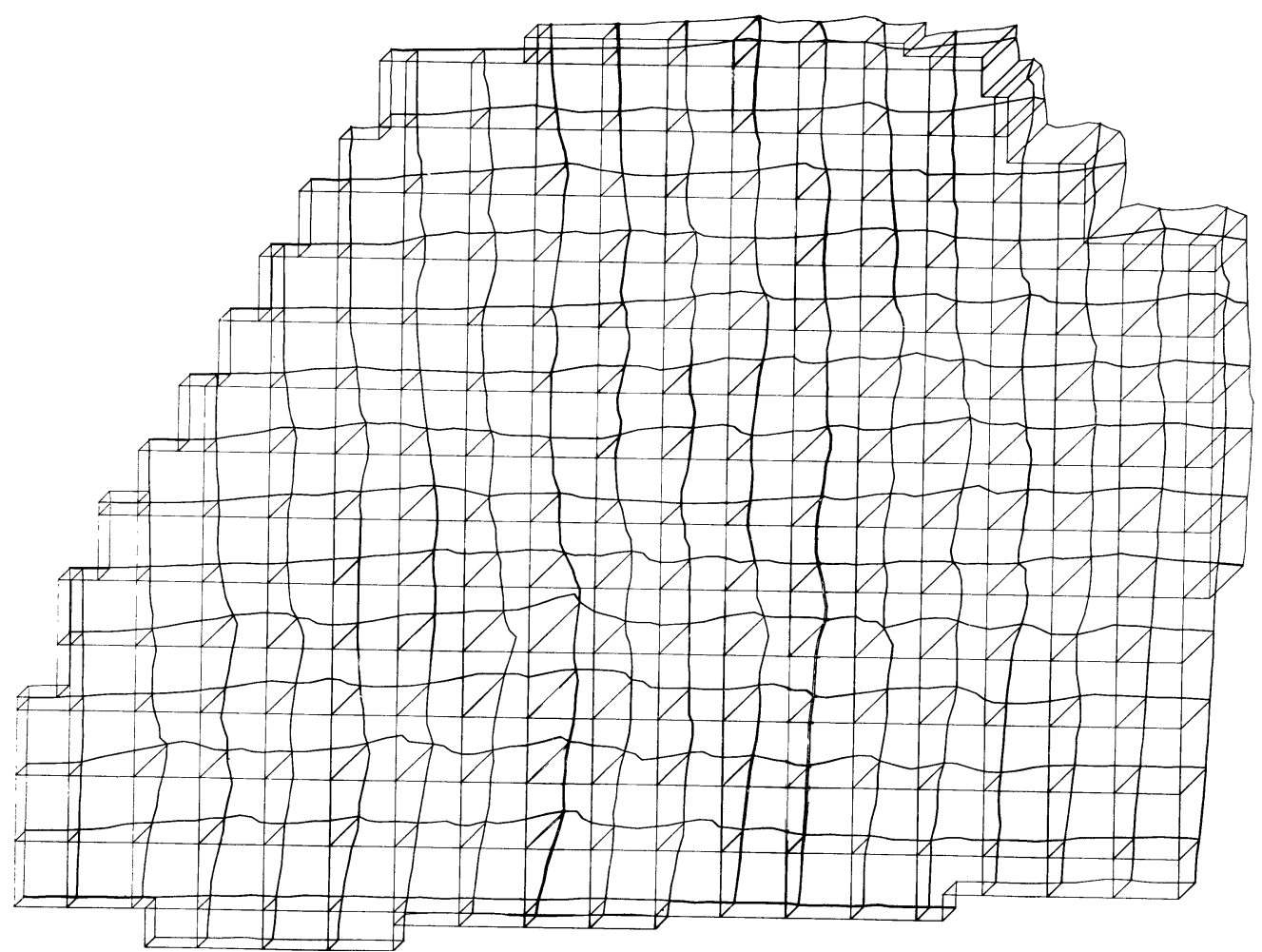

d. 現況立体図 


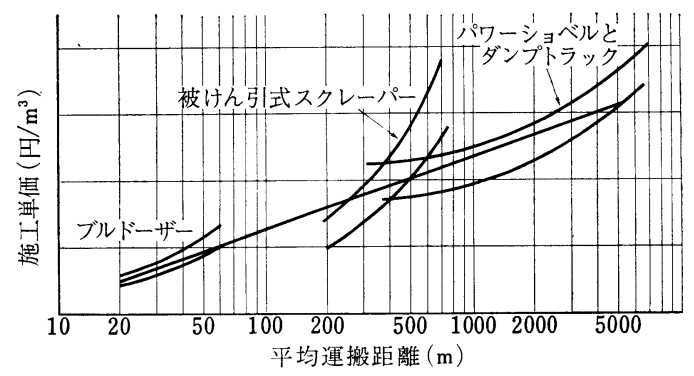

図-37 土量配分における単価の仮定の例

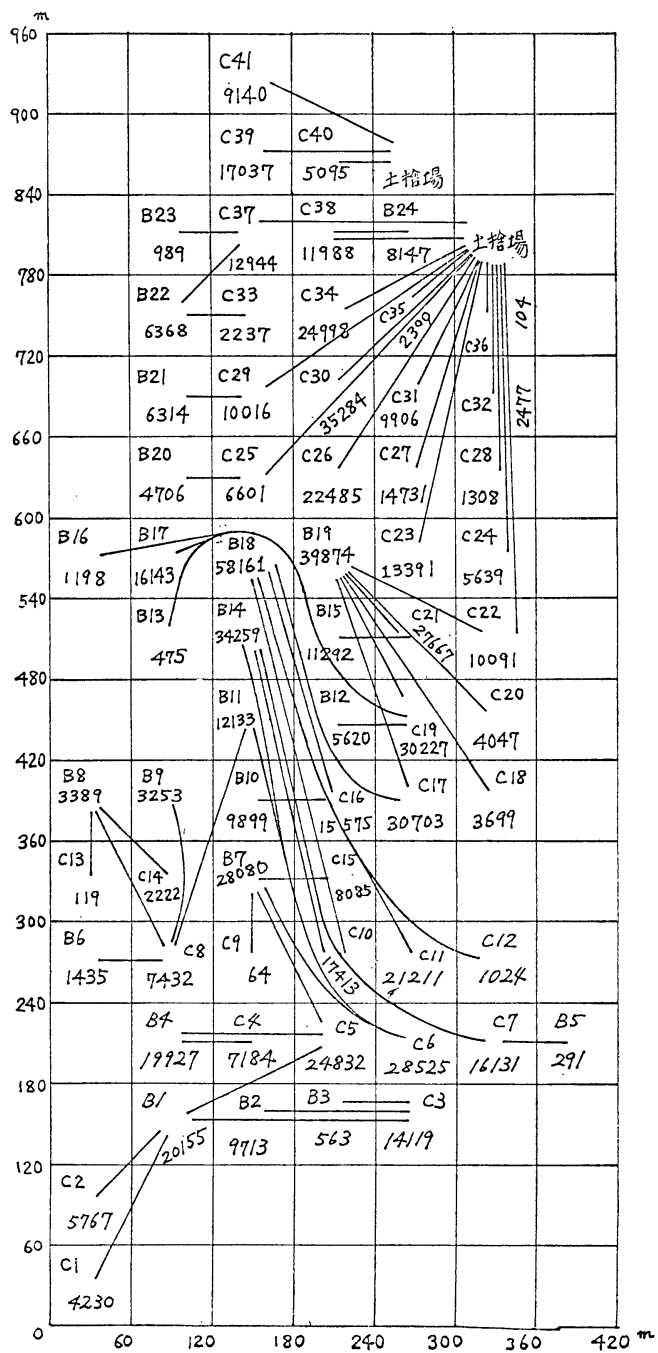

図-38＼cjkstart経験法による土量配分（費用：1.495億円）

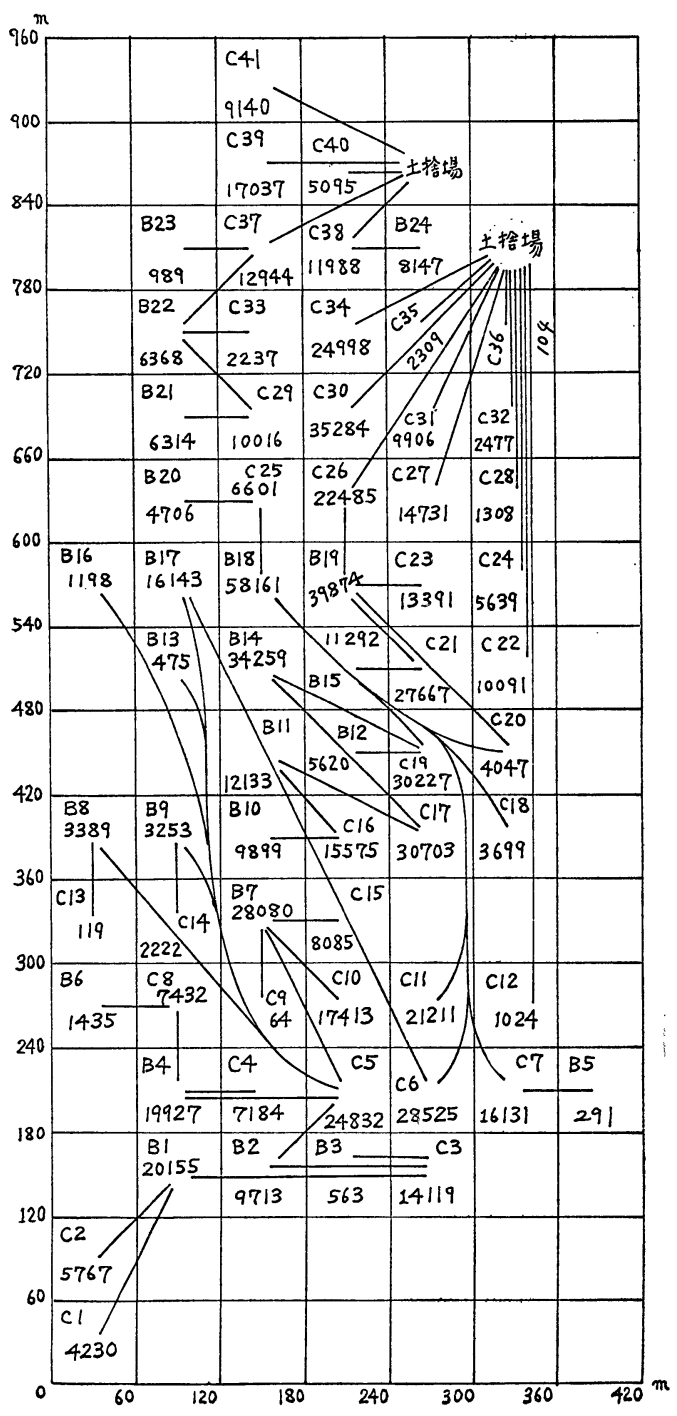

図-39 線型計画法による土量配分（費用：1.454億円） 